\title{
Passive Analysis of the Effect of Window Size and Position on Indoor Comfort for Residential Rooms in Kumasi, Ghana
}

\author{
Koranteng, $\mathbf{C}^{1}$, Essel, $\mathbf{C}^{\mathbf{1}}$, Nkrumah, $\mathbf{J}^{2}$ \\ Department of Architecture, Kwame Nkrumah University of Science and Technology ${ }^{1}$ \\ Development Office, Kwame Nkrumah University of Science and Technology ${ }^{2}$
}

\begin{abstract}
The amount of solar radiation through the fenestration of a building into the interior space is a key factor in assessing the indoor comfort and the eventual energy used in cooling off these spaces. In predominantly hot humid regions like Ghana which receives sunlight all year around, buildings and for that matter windows should be oriented to minimize solar gain and maximize natural ventilation. Windows are possibly the most complex and interesting elements in every habitable structure. Heat loss and heat gain through a window will not only depend on the type of window and its properties alone but also the size and the position of the same. This paper describes an investigation into the consequence of window sizes (varied wall-to window -ratio) and it's positioning on indoor thermal comfort for residential buildings in Ghana. A typical room of $3 \mathrm{~m} \times 4 \mathrm{~m}$ was parametrically simulated using the Tas tool. Various window sizes with diverse WWR were then probed into with varying positions (low, middle and high). The result showed that the ideal window to wall ratio for achieving almost comfortable indoor conditions should be between 10 to $40 \%$. Meanwhile, the various positions of the windows did not seem to have any effect on the indoor temperature values since all the values were the same. The study should lead to an improved residential design with appropriate window sizes and correct positions which will ensure indoor comfort and thereby reducing the total energy used in cooling.
\end{abstract}

Keywords: Window size, Thermal Comfort, Passive, WWR, Tropical region.

\section{INTRODUCTION}

Ever since the world's energy crisis in the 1970's, it has become paramount for countries to find ways of reducing its energy usage in all aspects. Buildings account for about $40 \%$ of the global energy consumption and contribute over $30 \%$ of the $\mathrm{CO}_{2}$ emissions. A large proportion of this energy is used for thermal comfort in buildings (Yang, 2012). One area where energy used could be reduced within the building and construction industry is through the use of natural ventilation (Hassouneh et al., 2010). Apart from natural ventilation, the use of zero energy to provide comfort within indoor spaces has its health benefits (Wolkoff, 2012). The main medium through which fresh outdoor air can ventilate an interior space is the fenestration window.

In the building sector, the increased use of airconditioners, inefficient curtain walls and sliding windows, and the lack of sustainable design principles, especially in office buildings have contributed to the present energy situation (Koranteng, 2010). The overall energy performance of a window assembly is dependent not only on the glazing and frame materials themselves, but on a number of architectural and interior design decisions (Carmody et al., 2007). Most often than not, building designers make such decisions based on the cost involved in providing such elements.

Architecturally, the hot and humid region is one of the hardest climates to ameliorate through design. This is due to the high humidity and daytime temperatures that result in high indoor temperatures exceeding the ASHRAE summertime comfort upper limit of $26^{\circ} \mathrm{C}$ for most of the year (Hyde and Sabarinah, 2008). Givoni (1994) reported that in hot humid regions the provision of effective cross ventilation under the local wind direction is the major factor that may affect the building orientation. Air movements inside a building depend not only on external wind velocity, but also largely on the architectural parameters. Architectural means for achieving this aim include conventional design element such as position and orientation of building, roof shape, balcony configuration, type and location of windows, partition and furniture arrangement (Al-Tamimi et al., 2011).

It is also possible that the window size and its position will also affect air movement inside the spaces thereby affecting the comfort within. The potential of the solar penetration through windows in hot climate, and its effect on the elevation of the indoor temperature, depends greatly on the orientation of the windows (Givoni, 1994).

In the present study, parametric numerical simulations were conducted to investigate the outcome of window size, where it's positioned on the façade on indoor comfort. The objective is to ascertain an ideal window size and position and for residential windows towards a thermally comfortable indoor spaces.

\section{LITERATURE REVIEW}

\subsection{Windows/Glazing}

According to the Carmody et al. (1996) a window has been defined as an opening in a wall, door and roof of a 
building or a vehicle that allows the passage of light and, if not closed or sealed, air and sound. The window as a building element has come a long way from its nonexistence in primitive homes to a single shutter and a glass pane even for residential homes in contemporary architecture. Al-Saadi (2006) and Datta (2001) together present an apt description of glazed windows as components that allow natural light, offer a visual communication with outdoors, reduce the structural load and enhance the aesthetic appearance of buildings. A shaded and well positioned window on a building can go a long way into reducing the energy usage of the building as reported by Szokolay (2004). Furthermore, the area of exterior wall to the area of windows/glazing can also affect the thermal conditions within a building, thus the window-to wall ratio (WWR) of the building.

Windows contribute significantly to both heating and cooling energy consumption of residential buildings. For instance Yoo et al. (2005) stipulated that that almost 30\% (or 0.11 quads, $0.12 \mathrm{EJ}$ ) of the total energy needed to condition residential buildings is attributable to heat transfer through windows

Windows, doors, and skylights have a significant impact on the thermal performance of the building envelope. Windows can also have a strong influence on the use, productivity, and comfort of the people who occupy the building (Al-Tamimi et al., 2011). Study reported by Jinghua (2008) showed that heat gain through the exterior window accounts for $25-28 \%$ of the total heat gain, adding to the infiltration. It is up to $40 \%$ (Al-Tamimi et al., 2011) in hot summer and cold winter zone. Carmody et al. (2007) stipulate that high performance windows have benefits such as increased comfort, reduced condensation problems, heat gain control without losing light and view, reduced fading from ultraviolet light etc. The authors' further comment that cost for mechanical equipment in the house if situation warrant that is also reduced by high performance windows.

Bokel (2007) studied the effect of window position and window size on the energy demand for heating, cooling and electric lighting. The total energy demand was calculated with the dynamic thermal program Capsol which simulates the total yearly energy demand for lighting, heating and cooling. The study concluded that facades should have a WWR of about $30 \%$ of the façade area, where the window is positioned in the top half of the facade. WWR between 20 to $40 \%$ is also very acceptable whiles greater WWR does not have any effect on the lighting loads. The study further asserted that when a window position is considered, it does have a significant effect on the primary energy demand for lighting (ibid).

A study by Gyimah and Tetlow (2014) concludes that in Ghana, 'almost all newly built residential estates have their windows as sliding. These windows are made up of aluminium frames and glass with low resistivity to heat. Just the material composition allows so much heat into the buildings and this makes them very uncomfortable to live in unless one uses a fan and in some cases airconditioning. This shift is attributed to the aesthetic value of these windows and with the building more aesthetically pleasing, the value of the building goes up in terms of price' (pp.30). From the conclusion above, it has become imperative that researchers come up with the appropriate glazing type, sizes, position and orientation that will minimize the sun's effect within the interior spaces of residential buildings.

\subsection{Thermal Comfort and Passive designs}

All humans within an indoor space might want to feel comfortable if surrounding conditions begin to suggest discomfort. Pino et al. (2012), defines thermal comfort as the physical and psychological wellness of an individual when temperature, humidity, and air movement conditions are favourable for the activity that has to be developed. According to Indraganti (2011), people either modify the environment or adapt themselves behaviourally or do both to remain comfortable in a thermal environment, through several adaptive control actions. It is when these adaptive measures fail or is insufficient that the active measures such as the use of air-conditioners are introduced.

Brager and De Dear (2000) suggested that current development of adaptive concept in thermal comfort research has underlined the importance of exploring same in different environmental contexts. The authors further assess that occupant's control over the environment could vary significantly between working environment (offices) and living environment (houses). In their own houses, people play an active role in ensuring their living environment is as comfortable as possible. In comparison with offices, occupants in houses have more freedom (flexibility) to control their own personal and environmental conditions in the form of clothing adjustments, drinking more frequently, taking bath, opening of windows, and switching the fan or AC on, etc. The comfort of individuals in their homes also depend on which part of the planet they find themselves and the prevailing weather conditions that is pronounced around the area.

Climate responsive design (passive designs) of buildings is important not only because of the comfort and energy saving implications for its users, but also because it helps preserve valuable resources in our planet (La Roche and Liggett, 2001). The ASHRAE Standard 55 defines adaptive model as one that relates indoor design temperatures or acceptable temperature ranges to outdoor climate (ASHRAE, 2004). By this definition, natural ventilation is greatly valued in adaptive designs. Frontczak et al. (2012) in their study asserted that, respondents valued natural ventilation highly and it was very important for them that they could open a window in their home. Temperature control by natural ventilation is often the only means of providing cooling when mechanical airconditioning is not available (Rofail, 2006).

Thermal comfort designs basically looks at how equilibrium would be achieved with a space; thus individuals would not be too warm or too cold. This phenomenon is the neutrality temperature. According to Hyde (2000), the comfort zone is $2^{\circ} \mathrm{C}$ below and above the neutrality temperature. Szokolay (2004) has set the 
comfort zone for $90 \%$ acceptability to be $2.5^{\circ} \mathrm{C}$ above and below the neutrality temperature, after Auliciems (1981) who did set the comfort zone for $90 \%$ acceptability to be $\mathrm{Tn}(+-) 2.5^{\circ} \mathrm{C}$ and $80 \%$ acceptability to $\mathrm{Tn}(+-) 3.5^{\circ} \mathrm{C}$ for both naturally ventilated and artificially ventilated spaces.

$$
\text { Tn }=17.6+0.31 * \text { To.av Eq. } 1
$$

Where: $\mathrm{Tn}$ is the neutrality temperature To.av is the mean monthly outdoor temperature

The recommendations by ASHRAE Standard 55 (ASHRAE, 2004) postulate that the acceptable summer time temperature range should be $23-26^{\circ} \mathrm{C}$. This should however ensure that at least $90 \%$ of occupants are thermally satisfied. Air temperature is often taken as the main design parameter for thermal comfort (Adebamowo and Akande, 2010). Heidari and Sharples (2002) have also suggested that air temperature alone is a good indicator of thermal comfort.

\subsection{Tropical Buildings}

Lauber (2005) and Givoni (1997) both assert that a building in the tropics means a confrontation of construction and function with extreme climatic condition. The climatic elements in tropical climate have both negative impact and positive impact to the building design. The most common impacts caused by the climatic parameters of tropical climate are temperature, relative humidity, solar radiation, rainfall and prevailing wind. Jamaludin et al., (2014) further affirm that in tropical climate, the solar heat and rainfall initiate continuous evaporation of the human body due to high amount of solar radiation received in the equatorial region. These excessive solar radiations cause discomfort condition of indoor environment in buildings. The authors therefore suggest that solar control design should be incorporated into building to reduce heat surplus from solar radiation.

The optimum orientation of residential building area in tropical climate is facing east or north and its major openings can greatly influence the solar heat gain according to Chauchan and Shah (2008). The authors suggest that North and east orientation has less direct solar direction towards the building envelope and therefore more windows should be placed at this orientation in order to allow natural ventilation. This however contradicts Szokolay (2004) who suggest that east and west facing walls should not have windows to avoid heat input. In the indoor environment, natural ventilation strategies could be categorised into cross ventilation, single-sided ventilation and stack ventilation to induce air movement in the building (Chung and Ahmad, 2014). This means that windows will have to be placed either on one side or two sides of the facades.

Rajapaksha et al., (2002) also assert that the indoor thermal environment is much affected by local climate, and therefore air movement through the building is necessary to decrease indoor discomfort due to overheating conditions in tropical climate. Whiles Kubota and Ahmad (2006) conclude that in warm and humid climates, external air movement assists in controlling the indoor environment, Jamaludin et al. (2014) emphasise that in recent times, occupants are likely to use air conditioners in achieving comfortable indoor environment in tropical climate. Such reliance on mechanical systems for health and comfort levels increases the energy consumption in residential buildings (Uno et al., 2012).

\section{METHODOLOGY}

Parametric simulation with the Thermal Analysis Software (Tas) was used as a means of analysing the indoor comfort within a typical reference room of $3 \times 4 \times 3 \mathrm{~m}^{3}$ commonly used as residential rooms within the climatic region of Kumasi, Ghana (Figure 1).

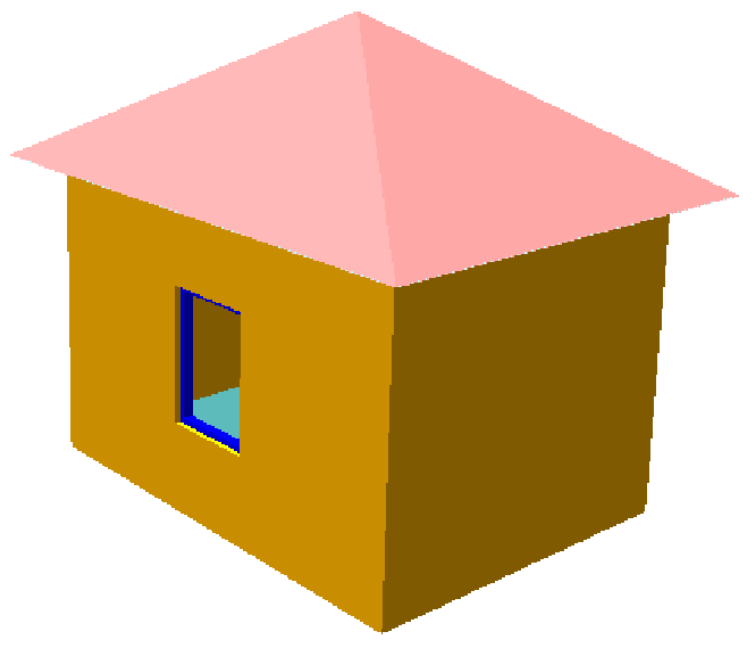

Fig.1: Typical room structure in Tas

The room is usually occupied by a person or two $\left(6 \mathrm{~W} / \mathrm{m}^{2}\right)$ and electric lighting load of $1 \mathrm{~W} / \mathrm{m}^{2}$. Equipment sensible heat is $16 \mathrm{~W} / \mathrm{m}^{2}$ with ventilation rate of $15 \mathrm{ach}$. The floor is made of concrete slab with tile finish. The ceiling is of a plywood finish with aluminium roofing sheets. Table 1 describes the material components of the room.

Table 1: Building fabric materials and their $U$-values

\begin{tabular}{|c|c|c|}
\hline $\begin{array}{c}\text { Building } \\
\text { Components }\end{array}$ & Materials Used & $\begin{array}{c}\text { U-value } \\
\text { (W/moC) }\end{array}$ \\
\hline Roof & $\begin{array}{c}\text { Aluminium roofing } \\
\text { sheets }\end{array}$ & 1.27 \\
\hline Wall & $\begin{array}{c}\text { 200mm sandcrete } \\
\text { wall with plaster }\end{array}$ & 1.14 \\
\hline Window pane & $\begin{array}{c}\text { 4mm single glazed } \\
\text { reflective glass }\end{array}$ & 5.80 \\
\hline Window frame & Aluminium frame & 5.88 \\
\hline Door panel & $\begin{array}{c}\text { 25mm hardwood } \\
\text { panel door }\end{array}$ & 3.20 \\
\hline Door frame & 50mm hardwood & 2.84 \\
\hline Floor & $\begin{array}{c}150 \mathrm{~mm} \text { concrete slab } \\
\text { with 50mm screed }\end{array}$ & 0.82 \\
\hline \multicolumn{2}{|c}{}
\end{tabular}

Mean temperature values calculated were compared first with the ASHRAE (2004) summer comfort temperatures of $23-26^{\circ} \mathrm{C}$ and then with the adaptive model based on the work of Auliciems (1981) and the recommendation by Szokolay (2004) for $90 \%$ acceptability was used to derive the comfort zone for Kumasi (See Table 2). 
International Advanced Research Journal in Science, Engineering and Technology

Vol. 2, Issue 10, October 2015

Table 2: Neutrality temperature for $90 \%$ acceptability: $(T n=17.6+0.31 *$ To.av $)$

\begin{tabular}{|l|l|l|l|l|l|l|l|l|l|l|l|l|}
\hline & JAN & FEB & MAR & APR & MAY & JUN & JUL & AUG & SEP & OCT & NOV & DEC \\
\hline To.av. & 26.5 & $\mathbf{2 8 . 6}$ & 28.4 & 27.9 & 27.6 & 26.6 & 25.5 & $\mathbf{2 5 . 3}$ & 26.0 & 26.4 & 27.0 & 27.3 \\
\hline Tn +2.5 & 28.3 & $\mathbf{2 9 . 0}$ & 28.9 & 28.8 & 28.7 & 28.3 & 28.0 & $\mathbf{2 7 . 9}$ & 28.2 & 28.3 & 28.5 & 28.6 \\
\hline Tn & 25.8 & $\mathbf{2 6 . 5}$ & 26.4 & 26.3 & 26.2 & 25.8 & 25.5 & $\mathbf{2 5 . 4}$ & 25.7 & 25.8 & 26.0 & 26.1 \\
\hline Tn -2.5 & 23.3 & $\mathbf{2 4 . 0}$ & 23.9 & 23.8 & 23.7 & 23.3 & 23.0 & $\mathbf{2 2 . 9}$ & 23.2 & 23.3 & 23.5 & 23.6 \\
\hline
\end{tabular}

Where $\mathrm{T}_{\mathrm{o}}$.av is the mean outdoor temperature; and $\mathrm{Tn}$ is low, middle and high on north and south orientations the neutrality temperature. The influence of window sizes adapted from the work of Bokel, (2007). Figure 3 shows a and position was investigated with 8 different window graphical presentation of the various window sizes and sizes with their respective Wall-Window-Ratio from 10 to positions.

$80 \%$ of the façade area with three window positions:
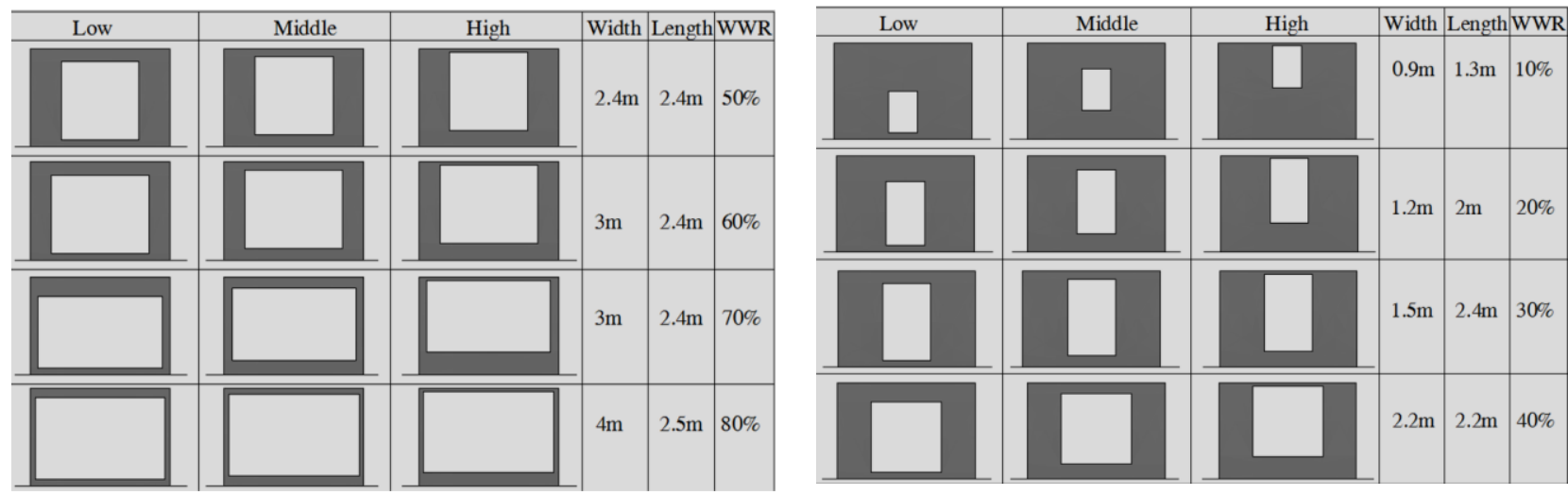

Fig. 3: Low, middle and high level window positions of all window sizes.

The low window position means that the window starts at the bottom of the façade which is $20 \mathrm{~cm}$ off the ground, the mid window means that the window is situated exactly at the middle of the façade, and the high window position means that the window ends at the top of the façade which has $10 \mathrm{~cm}$ ceiling space.

\section{RESULTS AND DISCUSSION}

The results of the simulation are shown in the Figures below. Figure 4 shows the mean annual indoor temperature values for the various window positions with respect to their sizes.

From the graph above, it is clear that window positions do not matter so much in terms of indoor temperature values since low, middle and high level windows all recorded the same temperature values from the simulation. According to Bokel (2007) however, the window position does have a significant effect on the primary energy demand for lighting when there is an active or passive user and day lighting system control. Therefore the position of windows on a façade will be based on other factors like good views, cost, demand for lighting etc.

Table 3 shows the mean monthly indoor temperature values for the various window sizes.

Although the Table shows a gradual appreciation of the temperature values as the window sizes increases, two basic elucidations can be given. First, seasonal climatic changes do affect temperature values and secondly, window-to-wall ratio (window sizes) also affects indoor temperature values. Fabi et al., (2012) however confirmed in their studies that aspects closely related to the type and size of the windows and its placements within façade affect the effectiveness of natural ventilation.

From the Table, ideal window sizes for residential buildings can be said to be between 10-40\%. Bokel (2007) stipulates $20-40 \%$ for office buildings. Roche and Milne (2004) also assert that smaller window sizes perform better than larger ones in terms of building comfort. Since general conditions are more favourable during the raining season, temperature values also fall steadily from the months of July through September (Table 4) for all window sizes. The dry season presents a hotter environment.

Al-Tamimi et al., (2011) also concluded in their studies of a tropical country that there were significant decreases in indoor air temperature in rooms when glazed area ratio of windows was changed from 50 to $25 \%$. According to Rathi (2012) the size, shape and location of a window have also been evaluated to affect the amount of ventilation as well as having psychological impacts on the occupants of the buildings. Psychological contentment is at its ultimate level when the proportion of windows is between 15 to $30 \%$ of the wall area (Imamoglu and Markus, 1973).

Figure 5 show results when the neutrality temperature which has been derived from the adaptive model (Table 2) is compared with the indoor temperature values simulated. 
International Advanced Research Journal in Science, Engineering and Technology

Vol. 2, Issue 10, October 2015

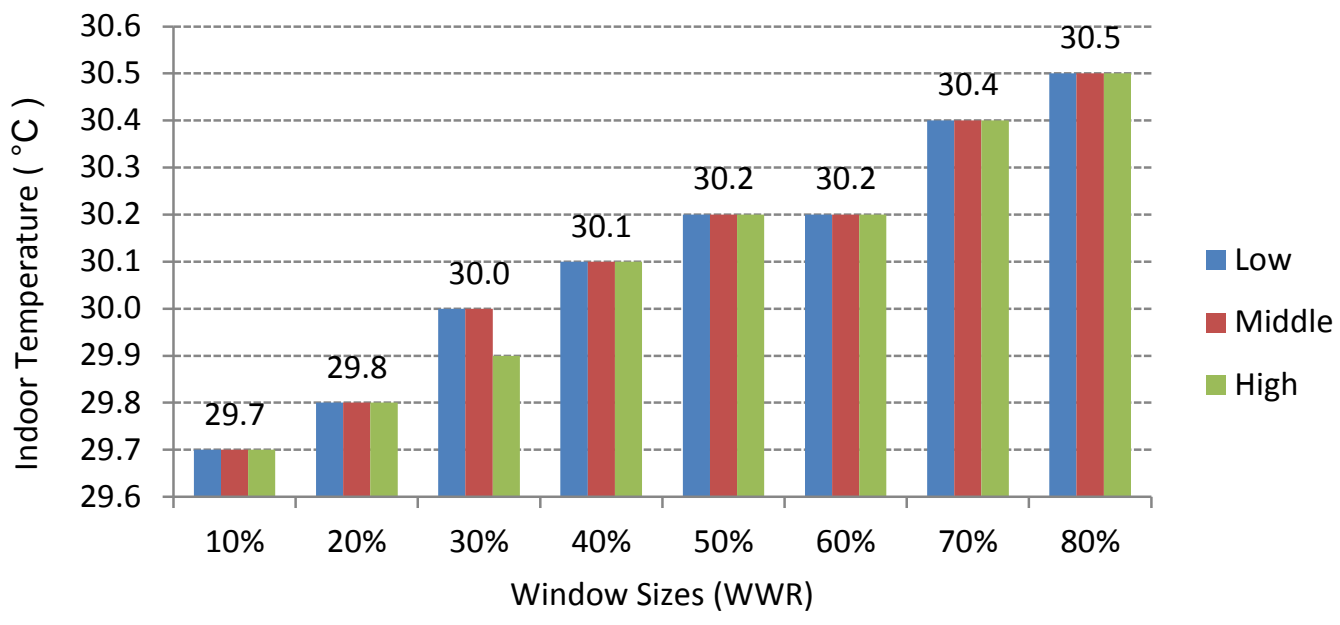

Fig. 4: Mean annual indoor temperature values for the various window positions and sizes.

Table 3: Mean monthly simulated indoor temperature values for various window sizes

\begin{tabular}{|l|c|c|c|c|c|c|c|c|}
\hline \multirow{2}{*}{ Months } & \multicolumn{10}{|c|}{ Window Sizes } \\
\cline { 2 - 9 } & $\mathbf{1 0 \%}$ & $\mathbf{2 0 \%}$ & $\mathbf{3 0 \%}$ & $\mathbf{4 0 \%}$ & $\mathbf{5 0 \%}$ & $\mathbf{6 0 \%}$ & $\mathbf{7 0 \%}$ & $\mathbf{8 0 \%}$ \\
\hline JAN & 30.0 & 30.1 & 30.2 & 30.3 & 30.5 & 30.5 & 30.7 & 30.8 \\
\hline FEB & 31.0 & 31.1 & 31.2 & 31.3 & 31.4 & 31.5 & 31.6 & 31.8 \\
\hline MAR & 31.5 & 31.6 & 31.7 & 31.8 & 32.0 & 32.0 & 32.2 & 32.3 \\
\hline APR & 30.7 & 30.8 & 30.9 & 31.0 & 31.1 & 31.2 & 31.3 & 31.4 \\
\hline MAY & 30.7 & 30.8 & 30.9 & 31.0 & 31.2 & 31.2 & 31.3 & 31.5 \\
\hline JUN & 28.9 & 29.0 & 29.1 & 29.2 & 29.4 & 29.4 & 29.6 & 29.7 \\
\hline JUL & 28.3 & 28.4 & 28.5 & 28.6 & 28.7 & 28.7 & 28.9 & 29.0 \\
\hline AUG & 27.5 & 27.6 & 27.6 & 27.7 & 27.8 & 27.8 & 27.9 & 28.0 \\
\hline SEP & 28.0 & 28.1 & 28.2 & 28.3 & 28.4 & 28.5 & 28.5 & 28.7 \\
\hline OCT & 29.4 & 29.5 & 29.6 & 29.7 & 29.8 & 29.9 & 30.0 & 30.2 \\
\hline NOV & 30.2 & 30.4 & 30.5 & 30.6 & 30.7 & 30.8 & 31.0 & 31.1 \\
\hline DEC & 30.6 & 30.7 & 30.9 & 31.0 & 31.1 & 31.2 & 31.3 & 31.5 \\
\hline
\end{tabular}

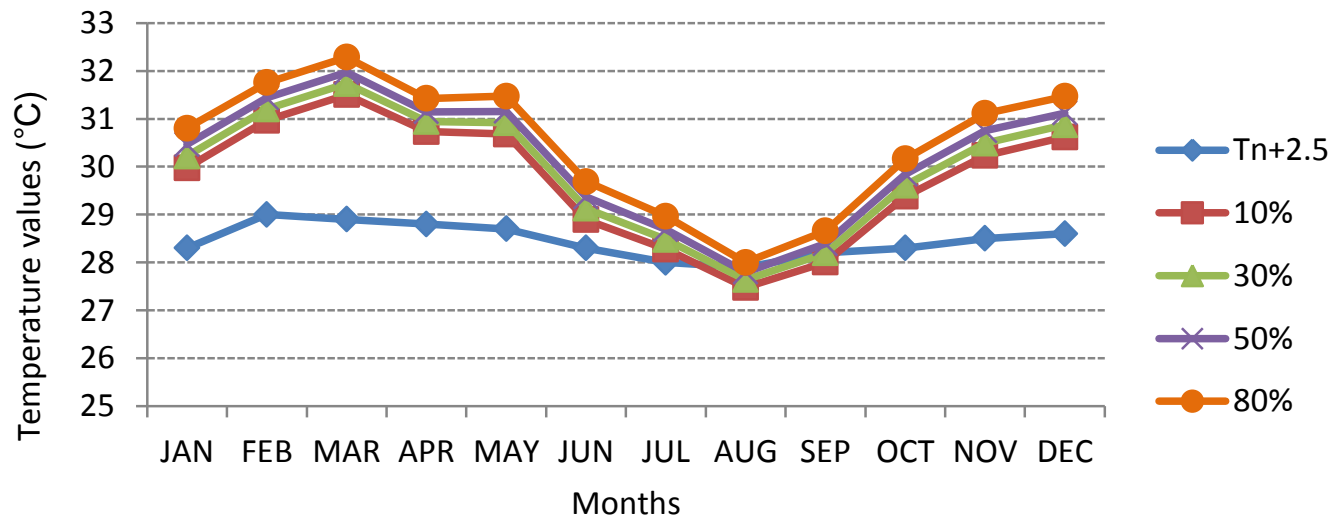

Fig. 5: Upper limit of neutrality temperature compared with simulated temperature values.

The Figure shows how the various window sizes indoor comfort.

performed in comparison with the neutrality temperature. The maximum, minimum, mode and quartile ranges are The closest set of windows to the neutrality temperature is presented in Figure 7. From the diagram, window sizes up the 10 and $30 \%$ which occurs during the wet season (May- to $40 \%$ seems plausible for residential buildings since it September). Other factors such as shading, window indoor temperature values are reasonably within ranges materials, facade insulation, and thermal mass all have to purported by some thermal comfort researchers for be explored to know their synergistic effect on building tropical climates. 
International Advanced Research Journal in Science, Engineering and Technology

Vol. 2, Issue 10, October 2015

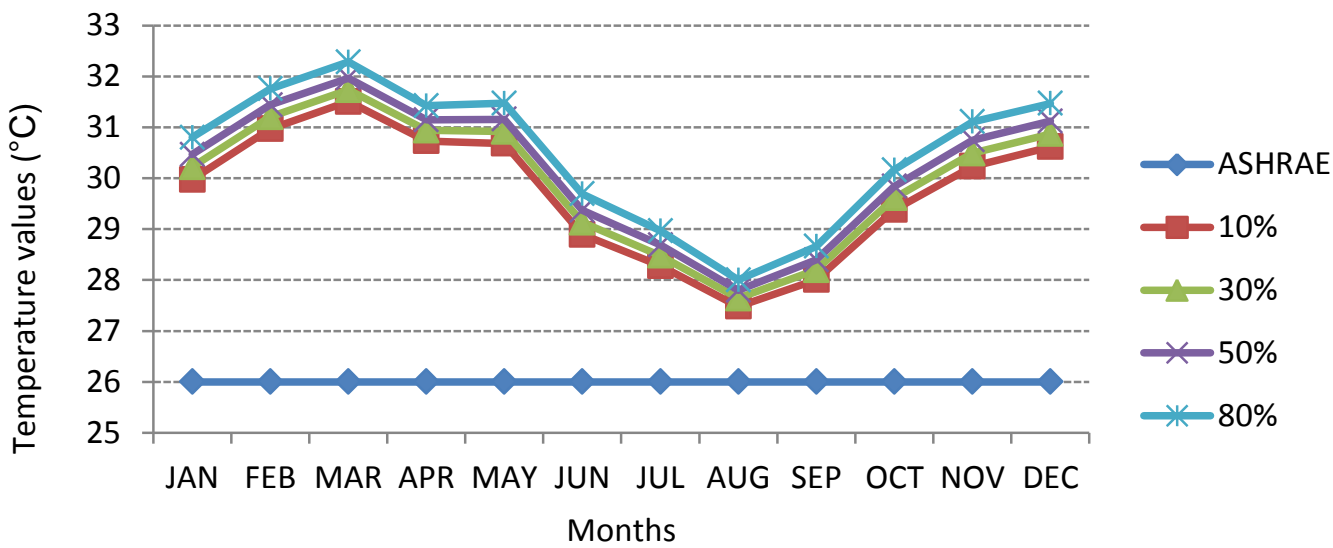

Fig. 6: ASHRAE comfort temperature compared with simulated values.

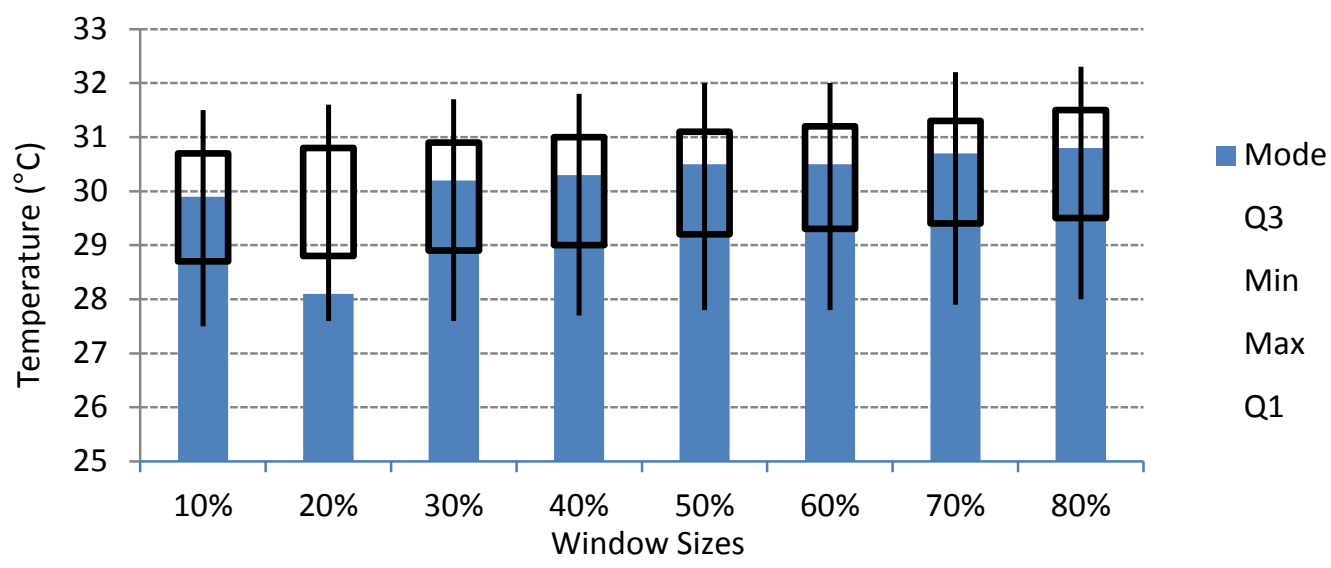

Fig. 7: Mean values for simulated temperature values

\section{CONCLUSION AND RECOMMENDATIONS}

Through parametric simulation, the effect of window sizes and position on indoor temperature has been studied. The study have shown that in terms of internal temperature comfort, the position of windows on building facades have no effect though other researchers have documented on the effect of window position on other parameters like primary energy demand for lighting and the amount of ventilation. The study has also shown that window sizes between $10-30 \%$ are ideal for residential buildings though $40 \%$ is tolerable. The adaptive model which relates the outdoor localised climate to the indoor seemed closed to the simulated indoor temperature values. In effect, attention should be paid to adaptive measures such as orientation, shape, shading etc when designing and building. It is also recommended that the use of shading devices like overhangs (walls and roofs), awnings and fins can be used to control solar gain and thereby reduce indoor comfort. Additionally, other parameters such as window orientation and sizes, position and orientation should also be studied towards the modelling of an ideal window for tropical buildings.

\section{REFERENCES}

1) Adebamowo, M. A., and Akande, O. K., (2010). Indoor Thermal Comfort for Residential Buildings in Hot-Dry Climate of Nigeria, pdf. Available at http://nceub.org.uk. Accessed: 15/11/2012
2) Al-Saadi, S. N., (2006). Envelope Design for Thermal Comfort and Reduced Energy Consumption in Residential Buildings. Master thesis. Architectural Engineering Dept. SAK, King Fahd University of Petroleum and Minerals.

3) American Society of Heating, Refrigerating and Air-Conditioning Engineers (ASHRAE) (2004) Standard 55-2004 \& Standard 551992, Thermal Environmental Conditions for Human Occupancy. ASHRAE, Atlanta.

4) Al-Tamimi, N. A., S. F. Syed Fadzil, and Harun, W.M.W., (2011). The Effects of Orientation, Ventilation, and Varied WWR on the Thermal Performance of Residential Rooms in the Tropics. Journal of Sustainable development, 4 (2), pp 142-149. Doi: 10.5539.

5) Bokel, R. M. J., (2007). The Effect of Window Position and Window Size on the Energy Demand for Heating, Cooling and Electric Lighting. Proceedings: Building Simulation 2007.

6) Brager, G., and de Dear, R., (2000). A Standard for natural ventilation. ASHRAE Journal 42 (10); pp. 21-27.

7) Carmody, J., Selkowitz, S., Arasteh, D., and Heschong L. (2007). Residential Windows. Third Edition. W.W. Norton Company, Inc., 500 Fifth Avenue, New York, N.Y.10110.

8) Carmody, J., Selkowitz, S., and Heschong, W. W. L., (1996). Residential Windows: A Guide to New Technologies and Energy Performance. Norton and Company. Available at http://www.wwnorton.com. Accessed 23/11/ 2014.

9) Chauhan, K., and Shah, N., (2008). "A study on Sustainable Urban Environment with climatic consideration in Housing Planning," Glob. J. Environ. Res. 2 (1); pp. 12-17.

10) Chung, L.P., and Ahmad, M. H., (2014). "Application of CFD in Prediction of Indoor Building Thermal Performance as an Effective Pre-Design Tool towards Sustainability Institute Sultan Iskandar of Urban Habitat and High-rise," World Appl. Sci. J., vol. 30, pp. 269-279. 
11) Datta, G., (2001). Effect of fixed horizontal louver shading devices on thermal performance of building by TRNSYS simulation. Renewable Energy 23 (3-4), pp 497-507.

12) Fabi, V., Andersen, R.V., Corgnati, S., Olesen, B.W., (2012). Occupants' window opening behaviour: A literature review of factors influencing occupant behaviour and models. Building and Environment 58; pp.188-198.

13) Frontczak, M., Andersen, R.V., Wargocki, P., (2012). Questionnaire Survey on Factors influencing Comfort with Indoor Environmental Quality in Danish Housing. Build Environ; (50):5664.

14) Givoni, B., (1997). Climate considerations in building and urban design. USA: Van Nostrand Reinhold, pp. 109.

15) Givoni, B., (1994). Passive and Low Energy Cooling of Buildings. Van Nostrand Reinhold; pp. 262.

16) Gyimah, K. A., and Tetlow, D., (2014). Achieving Energy Efficiency and Aesthetics through Windows in the Tropics. JENRM, 1 (1), pp 29-35

17) Hassouneh, K., Al-Shboul, A., and Al-Salaymeh, A., (2010). Energy Rating Windows for Residential Buildings. Int. Journal of Thermal \& Environmental Engineering. 1 (2), pp 67-74

18) Heidari, S., and Sharples, S., (2002). A Comparative Analysis of Short-Term and Long-Term Thermal Comfort Surveys in Iran. Energy and Buildings, 34, pp 607-614. Available at http://dx.doi.org/10.1016/S0378-7788(02)00011-7. Accessed $19 / 10 / 2012$

19) Hyde, R., (2000). Climate responsive design - A study of buildings in moderate and hot humid climates. London: E and FN Spon; pp. 57.

20) Hyde, R. and Sabarinah, S.A. (2008) Bioclimatic Housing, Innovative Designs for Warm Climates. Earthscan, UK and USA

21) Imamoglu, V., and Markus, T. A., (1973). The Effect of Window Size, Room Proportion and Window Position on Spaciousness Evaluation of Windows. Windows and their functions in architectural design, Istanbul.

22) Indraganti, M., (2011). Thermal comfort in apartments in India: Adaptive use of environmental controls and hindrances. Renewable energy; (36), pp. 1182-1189.

23) Jamaludin, N., Khamidi, M.F., Wahab, S.N.A., Klufallah, M.M.A., (2014). Indoor Thermal Environment in Tropical Climate Residential Building. E3S Web of conferences 3, 01026. DOI: 10.1051/e3sconf/20140301026.

24) Jinghua,Y. (2008). Low-energy envelope design of residential building in hot summer and cold winter zone in China. Energy and Buildings, 40; pp. 1536-1546.

25) Koranteng, C., (2010). The Energy Performance of Office Buildings in Ghana, Journal of Science and Technology, JUST, Vol.30, No.2, pp 114-127.

26) Kubota, T., and Ahmad, S., (2006). "Wind Environment Evaluation of Neighbourhood Areas in Major Towns of Malaysia," J. Asian Archit. Build. Eng., 5(1); pp. 199-206.

27) La Roche, P., Liggett, R. (2001). A Web Based Assistant for the Design of Climate Responsive Buildings. Architectural Science Review, 44, 437-448.

28) La Roche, P. and Milne, M., (2004). Effects of window size and thermal mass on building comfort using an intelligent ventilation controller. Solar Energy, 77; pp. 421-434. Available at www.sciencedirect. Com. Accessed on 12/05/2015.

29) Lauber, W., (2005). Tropical Architecture: Sustainable and humane building in Africa, Latin America and South-East Asia. New York: Prestel Publishing.

30) Pino,A., Waldo,B. W., Escobar, R., Pino, F.E., (2012). Thermal and Lighting Behaviour of Office Buildings in Santiago of Chile. Available at www.elsevier.com/locate/enbuild. Accessed $25 / 10 / 2012$

31) Rajapaksha, I., Nagai, H., and Okumiya, M., (2002). "Indoor Thermal Modification of a Ventilated Courtyard House in the Tropics," J. Asian Archit. Build. Eng., 1(1); pp. 87-89.

32) Rathi, P., (2012). Optimization of Energy Efficient Windows in Office Buildings for Different Climate Zones of the United States. Master's thesis, Kent State University. U.S.A.

33) Rofail, T. (2006). Natural Ventilation in Buildings. Windtech Consultants Pty Ltd. NEERG Seminar; pp.11

34) Szokolay, S., (2004). Introduction to Architectural Science: The Basis of Sustainable Design, First Edition, Architectural Press, Oxford, UK.
35) Uno, T., Hokoi, S., Ekasiwi, S.N.N., Hanita, N., and Majid, A., (2012). Reduction of Energy Consumption by AC due to Air Tightness and Ventilation Strategy in Residences in Hot and Humid Climates, pp. 407-414.

36) Wolkoff, P., (2012). Indoor air pollutants in office environments Assessment of comfort, health, and performance. International Journal of Hygiene and Environmental Health. In press. http//.dx.doi.org/10.1016/j.ijheh.2012.08.001.

Accessed 12/07/2015

37) Yoo, H.C., Oh, Y.H., Park, S.K., (2005). The optimal window system of office buildings considering energy efficiency. Journal of the Korean Solar Energy Society 25(4), 53-60.

38) Yang, L., Yan, H., Lam, J.C., (2012). Applied Energy 115: pp 164173. 